\title{
The Future of Distance Learning for Theological Education in Romania
}

\author{
Daniel Fodorean
}

\begin{abstract}
Romanian education system is in constant change, trying to distance itself from the communist approach to education, but also in fast integration with our contemporary new pedagogical methods. In the opinion of some observers especially careful on education, the changes that have occurred in the nearly 27 years since the fall communism in Romania has been too slow. Others believe that in these 27 years has made radical changes Romanian education. A kind of jumps from modern approaches to postmodern approaches, from traditional education methods in education, using innovative pedagogical methods almost most. Distance education has found its place in education specific legislation in 1995, but the first program of distance learning in higher education was launched in the academic year 1998-1999. In theology, the situation was even more different in that it was only in 2005 launched the first distance learning program in the field of theology. This article aims to evaluate and demonstrate that the distance education in theology is the only possible path of development, thus ensuring the future for training religious ministers in Romania.

KEY WORDS: theology, education, distance learning education, online education, university
\end{abstract}

\section{Distance Learning General Considerations}

omania is a former communist country that has had an important
political change following the popular revolution of 1989. This led to the commencement of the democratization of the Romanian 
society among which was counted also the education. At least the theoretical level, education is a national priority, but practically education system faced many organizational and legal changes and did not receive adequate funding. Pre-university education system in Romania is organized on several educational levels: preschool (0-3 years old), preschool (3-6 years old), primary (grades 0-4), middle school (grades 5-8), high school (grades 9-12). University education is composed of undergraduate studies, master, and doctoral studies and almost all of these can be followed in the residential, part-time and distance learning programs. The first law of education, after the beginning of democracy in Romania, launched for the first time formally distance learning education ${ }^{1}$ as a possible form of study. These provisions represent is a serious turning point in the approach to education in Romania, opening the possibility that in addition to traditional education and modern education to exist, even if it took until 1998/1999 for a first university degree can be studied in the form of distance education.

Even if Western countries this form of education there long, University of London was the first institution in the world offering programs for distance learning since 1858 in Romania "the first university in Romania to offer this alternative was Academy Economic Sciences in Bucharest in 1998, and a year later the University of Bucharest launched a similar offer." ${ }^{2}$ Distance education as a way of study has not been implemented at all in the pre-university education system, being present only in higher education. Areas, where such programs were implemented for the first time, were the technical and economic one, but humanist sciences opposing resistance at first.The total refusal came from universities that prepare students in health care (nurses, doctors, pharmacists, dentists, etc.) without even trying a combined form of residential courses and online courses. In this group of almost total rejection of distance learning joined, as an opinion, even theological schools in Romania, convinced that students may not have adequate training in this form. Currently, in Romania, most universities offer distance learning programs for some areas, both undergraduate, and master programs. After 10 years since the launch of the first program of distance learning in Romania, according to statistics from $2008,{ }^{3}$ the 
number of students in these programs has increased very quickly reach 260911 in public education, or nearly 30\% of all students and in private education were 106335 students representing about 48\% of the total number of students in private education. So, we can notice a greater openness to innovative pedagogies at private universities, all of which were founded after 1989, and rapid increase students, in public universities, interested in distance education. This showed that in Romania, as in other countries, the trend in education is increasingly embracing distance education. After 2009, the student population began to decline. According to Mariana Bichir, "Romania started in 1990 to more than 200,000 students across the country, and reached its peak in 2007 when they were enrolled in public or private schools of about 907000 young people." Such as "the number of students has dropped sharply in recent years: from 907 353 people in 2007, total crashes by almost half -464592 students enrolled in higher education system in 2012."

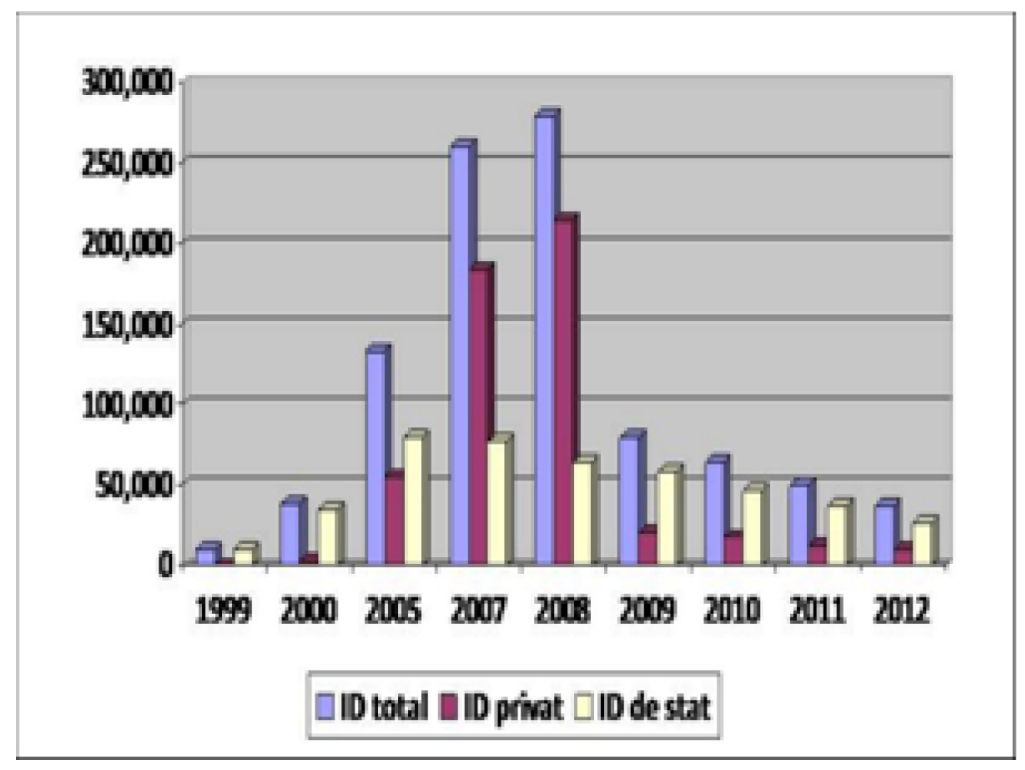

The graph above shows how this decrease in the number of students affected significantly even distance learning. Bara violet represents the total number of students in distance learning and bar garnet is a represent total number of students who are integrated into distance 
education in state universities, and the yellow bar represents the number of students integrated into distance education in private universities. The main reason for this decrease in the number of students is that increasingly many students failed to pass the baccalaureate exam for high school completion which prevented them to be admitted as students at universities.

Besides the issue of education in Romania philosophy, and history of distance education, which were discussed above, need to be considered and also the legal aspect regarding distance learning. According to the two laws of education adopted in the last twenty-two years, Law of Education $84 / 1995^{5}$ and Law of National Education no. $1 / 2011,{ }^{6}$ the three existing forms of education today in Romanian universities are residential education programs, parttime education programs, and distance learning programs. Law of Education 84/1995 shows another organizational form of education beyond those three, namely education of evening classes, 'seral.' According to Law of National Education no. 1/2011 universities can have only distance learning program for the undergraduate and master's program may be in the form of full-time or part-time. Doctoral studies can be only in the form of full-time learning. Each distance learning program must be accredited by the only agency that has competence in this regard, namely The Romanian Agency for Quality Assurance in Higher Education. Government and the Romanian Agency for Quality Assurance in Higher Education have developed certain decisions for the operation and evaluation of a distance learning program, such as Government Decision 1011/2001, Order of the Minister of Education 6251/2012, and documents that relate to the organization of university studies in general, as Government Decision 1175/2006.

Based on whether educational, historical and legal, distance learning in Romania is understood as follows:

1) an alternative form of learning (Law 1/2011)

2) a form of organization of educational processes that provide students / trainees the opportunity to personally choose the place and time in which to train / educate themselves (OMECTS $6251 / 2012$ ) 
3) a training program whose components are dominant: the use of educational resources specific to computerized communications systems remotely self-training and selfassessment and tutorial system (Decision no. 1011/2001).

Such as "distance learning is a flexible form of education that gives students the opportunity to choose the place, space, and timing of benefit from educational services; to study individually and independently and benefit from instructional support / noninstructional respectively—the tutorial system." ${ }^{\prime 7}$

\section{Distance Learning and Theological Education}

Rapid computerization of society has influenced the education system. New information technologies and communication, changing insight educational practice, their implementation is regarded as one of the most important issues at this end of the century, raised to the rank of national policy. And this happens because "online education challenges widely-held educational assumptions and casts the traditional skills associated with teaching in a different light." ${ }^{8}$ Even theological studies are no exception to these challenges. Of the 19 universities of Theology in Romania only one university, the Baptist Theological Institute of Bucharest offers a distance-learning program in theology.

Theological Seminaries worldwide train clergymen through distance learning. For example, a web resource of the US recommends those who want to prepare to serve the Orthodox Church as "there are opportunities for Distance Education in the Orthodox Church. ${ }^{9}$ The Institute of Orthodox Studies makes words of high appreciation for distance education:

Distance learning was once a poor substitute for other forms of education, being restricted chiefly to private reading and occasional essays or examinations submitted through correspondence. This format, we are happy to say, is a thing of the past. The Institute's Certificate Program brings your 
studies to live in new and creative ways. Since our Institute was founded, we have consistently worked to be at the forefront of Orthodox Distance Learning, and this has included developing and refining an extraordinary set of resources and tools, each of which helps to make the Distance Learning experience rich, interactive and a powerful medium for in-depth study of Orthodox Christianity. ${ }^{10}$

These are not isolated cases but "in the last 10 years, a number of distance education programs in Orthodox Theology have emerged, including three that are run by our own Russian Orthodox Church Outside Russia." ${ }^{11}$ Bishop Paul S. Loverde says that "Catholic Distance University is a paradox: it exists in order to eliminate distance. Its mission is to reach out to the ends of the earth with the message of the Gospel so that it can collapse that distance into encounter."12 Leaders from "Baptist Bible Seminary offers online academic courses for every degree program, making your seminary education flexible and convenient." ${ }^{13}$ All these facts lead us to conclude that Christian theology, no matters the denomination, it can be studied through distance learning programs.

What makes theological schools of higher education in Romania to be restrained toward distance learning? Without claiming to have a complete answer to this question, following the positions expressed by some Christian denominations or theological schools of Romania may conclude that there are two types challenges: conceptual challenges and institutional challenges. Surely every person and institution has the right to think freely, and this is because "when taking into discussion the issue of human rights and fundamental freedom , it is very hard to imagine a more fundamental freedom than freedom of region." ${ }^{14}$

Conceptual challenges have to do so with theology, and also with pedagogy. Briefly theological and practical reasons underlying not use the internet on large scale in formal and informal education are: 1) Fear of losing doctrinal accuracy; 2) Uncertainty as this means, the internet, and this method, distance education, have enough theological support in order to be used in the ecclesial area; 3) Theology is more focused on word than image. 
In debates on theological distance education in Romania were raised questions as "We risk losing our scripts without tutors day? If you set up ID (distance learning), will open the formation of a wave of theologians suspicious?"15 One of the participants in the discussion was written that "those who currently do theology 'for their lives,' can learn any form of education, including the Internet, without the right to ordination." ${ }^{16}$ Even if one can speak of an official position, these also shed hint that theological accuracy can be maintained only through the direct involvement of the clergy and church. Moving teaching and learning in a virtual space gives the impression decrease or loss of control over church doctrine. Secondly, among theologians exist uncertainty that this means, the internet, and this method, distance education, have enough theological support for to be used in the ecclesial area. All the actions described in the New Testament church seem to require direct involvement in the local community life of the believer, and in society. All the actions described in the New Testament church seem to require direct involvement in the local community life of the believer, and in society. However we see that church and some believers have been taught from a distance by the Apostle Paul through letters, which were nothing more than text theological, but these letters were used on the basis of direct knowledge, prior or subsequent writing and sending them. So we can say that the New Testament model is a combination of direct transmission and distance transmission of Christian teaching. The third conceptual element that can hinder the implementation of online education is that theology is focused more on the word and not so much on the image. God is immaterial and invisible and talked, and this speech of God is the basis of knowledge of God. This understanding has led to the belief that we can learn by reading theology books, the internet being a promoter not only of text, but also a promoter of images. In fact, there are no antitheological images to use in relation to theology, Jesus Christ used in his teachings direct visual elements known to his audience.

Additional challenges include theological and practical issues that had been raised as reasons for not using distance learning. One of these is precisely the danger that the student is captured by this means, the Internet, and get to become addicted to it, losing sight 
of other important issues for the life of a Christian, namely prayer, fasting, etc. Regarding the pedagogical challenges was more to do with the need to change the teaching style of professors. Professors of theology are generally ministers of churches that are involved in preaching, a specific form of proclamation and teaching. Moving from a traditional form of teaching an innovative shape and a different dynamic teaching as distance learning involves assisting teaching and acquiring a new skill set. Hede says:

One of the most significant issues facing instructors designing and teaching online courses is the temptation simply to replicate as nearly as possible the traditional classroom model (Ruth 2006). Newcomers to the world of online education often assume that the content of their courses needsn't be altered to account for the new instructional context and that the subject matter will translate seamlessly from one venue to the next. ${ }^{17}$

In the second kind of challenges that hinder the distance education to be much more widespread in Romania are institutional. What are the challenges and opportunities facing higher education system, seminaries, and theological schools when talking about this new system of teaching and learning? Each institution must look in their own backyard and think what impact would such a system in the following we will explore the ups and downs of distance learning from two perspectives: that of the student and the institution offering this system. Issues such as funding generally represent the challenges, accreditation, and staff and students demand from such a program. Due to a system still quite bureaucrat is a program accreditation is a process quite difficult. According to Elena David "this educational alternative is not cheaper than resident learning as happens in most European countries." ${ }^{18}$ We conclude that by solving these types of challenges, conceptual and organizational, would provide the possibility of distance learning in the field of theology to expand in Romania. 


\section{Alternative Theological Education in Romania A Hybrid Model}

To overcome the resistance that exists towards the implementation of distance theological education in Romania, and given the specificity of theological education, a solution would be to implement a hybrid model of online education and face to face education. Education face to face will take place at tutorial centers established in areas where students live. Education face to face tutorials take place in centers established in areas where students live. Even if $80 \%$ of the education process will ave place online, and only $20 \%$ of education will be through face to face meetings, this model will make the process of education to be more humane and more effective.

This model of hybrid model integrates best in the context of socio-cultural and religious realities in Romania and is supported by three arguments

1) Psihopedagogic Argument: A balanced student training is done both through interaction with the virtual world, but also by the real world.

People who walk in the distance learning student is called the virtual world, and by the term "virtual education is increasingly used in direct relation to the increasing presence of information and communication technologies in open and distance learning methodology." ${ }^{19}$ From the Christian point of view, technology serves the man, but a man should not be the slave of technology. This can lead to the danger of addiction by the virtual world. In order to avoid this institution should offer the student learning experiences even in a real community in accordance with university professor Apostol:

If the online interaction is used as a supplement to-or becomes a substitute for-texts, hours of class, lecture halls, virtual communities can pro-vocational re-lation fundamental changes in social and educational nature. Such a community 
is only possible by technology on, but it is not animated by it. A virtual community life can occur only in human communication, but while the quality of this communication can be enhanced and developed through technology, it is fundamentally governed by human factors, not technical. ${ }^{20}$

Total absorption of the student in the virtual world could have negative social consequences psychology and the student, which would make the process of learning not to be so effective.

2) Theological Argument: Education distance is done in the context of real relationships between the one who teaches and the learner.

The apostle wrote his epistles, in almost all cases, by some person or church that has met them before or after writing the letter . This makes an observation of the New Testament believers in the church and education can be done in a combination of methods, distance and face to face. All this approach in perfectly with the mission of the church, and that is to make disciples, but this can be done by "go into all the world and make disciples" and it involves a real and direct connection with the person next servant respectiva. Forming the church is part of the process of discipleship.

3) Legal Argument: The Romanian Agency for Quality Assurance in Higher Education required two face to face meeting for each class.

The Romanian Agency for Quality Assurance in Higher Education regulated by the regulation on distance education as "Every discipline/course promotes at least two tutorials activities each semester developed through direct meetings, face to face (AT)." ${ }^{21}$ Universities organizing distance learning programs have implemented this regulation, such as in Romania not only at universities that have programs theological, but all universities apply a hybrid distance education.

Tutorials and assisted activities through direct meetings may involve: 
- Synthetic exposures are presented and explained basic knowledge of the subject;

- Synthetic exposures that are organized at least 2 times per semester for each subject in the curriculum during intensive training;

- One conversation and group discussions where students can inquire, explain difficult topics;

- Distance interactive communication via email and the Internet, direct subsequent meeting.

- These direct tutorials are scheduled on Saturdays / Sundays or during the week in the afternoon or evening, at a time of 2-4 weeks.

\section{Conclusion}

Based on the study conducted I found that even if the theology has a specific content, and perhaps approach tutorials, future ministers of churches can be trained through distance learning programs. Distance learning program presents itself as a hybrid between online education and face-to-face meetings organized tutorials for each course. Also, given that rapid development in Romania Information Society, Romania being among the countries with the highest speed internet, I thin distance learning education will expand and will include increasingly more and field theological. Future of education in Romania, in a largely belongs, will be distance learning education.

NOTES

${ }^{1}$ Law of Education 84/1995 published in The Official Journal of Romania Part I, no. 1/ 5 January 1996, Article 15 (8)

2 Elena David, "Învățământul la distanță, noua tendință în educație", România Liberă, Noiembrie 24, 2010, See: http://www.romanialibera.ro/ societate/educatie/invatamantul-la-distanta--noua-tendinta-in-educatie207227 (Last accessed on April 14, 2015.)

${ }^{3}$ Elena David, "Învățământul la distanță, noua tendință în educație"

4 Mariana Bichir, "Educația României și Europa 2020: Reglementary care permite intrarea la facultate înainte de a lua bacalaureatul salvează 
România în statisticile UE", Curs de Governor, September 17, 2014, See: http:// cursdeguvernare.ro/educatia-romaniei-si-europa-2020-reglementarea-carepermite-intrarea-la-facultate-inainte-de-a-lua-bacalaureatul-salveaza-romaniain-statisticile-ue.html (Last accessed on April 14, 2015.)

${ }^{5}$ Law of Education 84/1995 published in The Official Journal of Romania Part I, no. $1 / 5$ January 1996, Article 15

${ }^{6}$ Law of National Education no. 1/2011 published in The Official Journal of Romania no. 18/ 10 January 2011, Articles 140, 361

7 "Motivația alegerii formei de învățământ la distanță", Universitatea Aurel Vlaicu, See: http://www.uav.ro/ro/departamente/invatamant-la-distanta (Last accessed on April 15, 2016.)

${ }^{8}$ Mark A. Maddix, et. al., Best practices of online education. A Guide for Christian Higher Education, (Charlotte: Information Age Publishing, 2012), 3

9 "Distance Education," See: http://goodguyswearblack.org/seminaries/ distance-education/ (Last accessed on April 15, 2016.)

10 "How Will I Learn? Interactive Distance Learning at its Best," See: http://www.sforthodoxinstitute.org/certificate-program/91-how-will-i-learn (Last accessed on April 15, 2016)

11 "Distance Education in Orthodox Theology," St. Nicholas Orthodox Church, McKinney (near Dallas) TX, See: http://orthodox.net/ redeemingthetime/2013/05/30/distance-education-in-orthodox-theology/ (Last accessed on April 16, 2016.)

${ }^{12}$ Cf: https://www.cdu.edu/ (Last accessed on April 16, 2016.)

${ }^{13}$ Online learning at Baptist Bible Seminary," See: https://www.summitu. edu/seminary/online-seminary-programs/ (Last accessed on April 16, 2016)

${ }^{14}$ Ioan Gheorghe Rotaru, "Religious Liberty-A natural human right," in Jurnalul Libertatii de Constiinta (2015): 601.

15 “Facultăți de Teologie: forme de învățământ," See: http://forum.teologie. net/viewtopic.php?t=938 (Last accessed on April 15, 2016.)

${ }^{16}$ Facultăți de Teologie: forme de învățământ," http://forum.teologie.net/ viewtopic.php?t=938 (Last accessed on April 15, 2016.)

${ }^{17}$ Brent A. R. Hege, "The Online Theology Classroom: Strategies for Engaging a Community of Distance Learners in a Hybrid Model of Online Education", Digital Commons @ Butler University (2010): 2 See: http://digitalcommons. butler.edu/facsch_papers/170 (Last accessed on April 17, 2016.)

${ }^{18}$ Elena David, "Învățământul la distanță, noua tendință în educație" Ibid.

${ }^{19}$ Olimpius Istrate, Educația la distanță. Proiectarea Materialelor (Botoșani: Agata, 2000), 19.

${ }^{20}$ Constantin-Gelu Apostol, et. alt., "Comunitatile virtual si învatamântul la distanta", Revista Informatica Economica, nr. 3 (19)/2001.

${ }^{21}$ Order 6251/2012 published in The Official Journal of Romania Part I, Part I, nr. 831 din 11 Decembrie 2012, art. 8 (2). 